\title{
The Impact of State Constitutional Right to Bear Arms Provisions on State Gun Control Legislation
}

The validity of state gun control legislation is measured by a number of state and federal constitutional requirements: equal protection ${ }^{1}$ and due process ${ }^{2}$ provisions; the privilege against self-incrimination $;^{3}$ and

1 Equal protection requirements seem to be of special significance to firearms legislation prohibiting certain classes of persons from possessing arms. These statutes are discussed in the text at notes 97-100 infra. They are generally upheld on the assumption that there is a rational basis for believing that individuals in the proscribed classes are more likely to misuse weapons than members of the population at large. See State v. Krantz, 24 Wash. 2d 350, 164 P.2d 453 (1945) (classification "crimes of violence" upheld as reasonable) and other authorities cited in note 97 infra. However, there are some indications that this assumption is not accurate for many of the classes these statutes define. See G. NEWTON \& F. Zimring, Firearms and VIOLENGe in American Life 82 (STAfF REport to the National Commission on the Causes and Prevention of Violence No. 7,1969 ) [hereinafter cited as NEWTON \& ZIMRING]. See generally Turner v. Fouche, 396 U.S. 346-(1969) ("[T] he traditional test for a denial of equal protection [is]: whether the challenged classification rests on grounds wholly irrelevant to the achievement of a valid state objective.") See also Grasse v. Dealer's Transport Co., 412 Ill. 179, 193-94, 106 N.E.2d 124, 132, cert. denied, 344 U.S. 837 (1952) (For a classification to be constitutional there must be: 1) real or substantial difference in kind of persons it defines, and 2) it must bear a rational relation to the evil to be remedied.); Allinder v. Homewood, 254 Ala. 525, 531, 49 So. 2d 108, 118 (1950) (classification must have rational basis).

2 Due process requirements have, as in other fields, a pervasive impact on gun legislation. See generally Duncan v. Louisiana, 391 U.S. 145, 147-48 (1967), for a listing of some of the protections afforded by due process requirements. Legislation that would confiscate weapons without compensation might be especially vulnerable to attack under due process doctrines. See Chicago, B. \& Q.R.R. v. Chicago, 166 U.S. 226 (1897). The due process clause might also affect such questions as whether a previous arrest may be grounds to deny a license for possession of a firearm and whether one who is denied a license is entitled to a hearing. These issues are not dealt with in this comment, but are mentioned only to alert the reader to some of the possible implications of the due process clause in the firearms area.

3 The privilege against self-incrimination is a serious restriction on the breadth of licensing or registration statutes. See Marchetti v. United States, 390 U.S. 39 (1968); Grosso v. United States, 390 U.S. 62 (1968); Haynes v. United States, 390 U.S. 85 (1968). See generally Newton \& Zimring, supra note 1, Appendix $\mathrm{K}$, at 263: Firearms Control and the Fifth Amendment; Mansfield, The Albertson Case: Conflict Between the Privilege against SelfIncrimination and the Government's Need for Information, 1966 SUP. Cr. REv. 103; McKay, Self-Incrimination and the New Privacy, 1967 Sup. CT. REv. 193; Note, Required Information and the Privilege against Self-Incrimination, 65 CoLUM. L. REv. 681 (1965). 
state, and possibly federal, ${ }^{4}$ constitutional right to bear arms provisions. ${ }^{5}$ Except for brief mention in several recent articles discussing the second amendment, the state arms provisions have been largely ignored ${ }^{6}$ in the extensive legal commentary generated by the recent cry for firearms control. ${ }^{\top}$ This comment attempts to fill this void.

4 The second amendment to the United States Constitution declares that:

A well regulated Militia, being necessary to the security of a free State, the right

of the people to keep and bear Arms, shall not be infringed.

The second amendment has not yet been held applicable to the states, either directly, or through incorporation in the fourteenth amendment due process clause. See United States v. Cruikshank, 92 U.S. 542 (1875) (holding that second amendment restricts only Congress). That conclusion was affirmed in Presser v. Illinois, 116 U.S. 252 (1886).

However, the Supreme Court has intimated that the states may not control arms in a manner that would conflict with the federal government's use of state militias for national defense. See Presser v. Illinois, 116 U.S. 252, 265 (1886). But the federal government's reliance on militias (National Guard) would not seem to require private possession of weapons in today's society. See text at note 30 infra. Thus, if the second amendment were applied to the states, it might have a very narrow range. Some commentators have urged, however, that the second amendment should apply to the states and that it should protect private possession of firearms. See text and note at note 25 infra.

Application of the second amendment to the states has been urged on two grounds: first, its language preserves the right to the "people" as opposed to the first amendment phrasing "Congress shall pass no law;" second, it should be incorporated into the due process clause of the fourteenth amendment in the same fashion that other basic guarantees have been incorporated. See Olds, The Second Amendment and the Right to Keep and Bear Arms, 46 Micr. ST. B.J. 15, 20 (1967); Rohner, The Right to Bear Arms: A Phenomenon of Constitutional History, 16 Catholic U.L. REv. 53, 68 (1966).

- The state provisions are cited and discussed in Part II infra.

6 Ironically, the recent enactment of a federal firearms statute accentuates this oversight. The Gun Control Act of 1968, 18 U.S.C. \$\$ 921 et seg. (Supp. IV, 1969), while re. jecting uniform federal regulation as a solution to the gun problem, seeks to prevent the interstate flow of firearms from undermining local controls. The scope of the Act is outlined in NEWTON \& ZiMriNG, supra note 1, at 105-11. The congressional intention to rely on local control entances the importance of state constitutional provisions that might limit state authority to enact gun control legislation. See Congressional Findings and Declaration following 18 U.S.C. \& 921 (Supp. IV, 1969):

Section 901 of Pub. L. 90-351 provided that:

(a) The Congress hereby finds and declares-

(I) that there is a widespread traffic in firearms moving in or otherwise affecting interstate or foreign commerce, and that the existing Federal controls over such traffic do not adequately enable the States to control this traffic within their own borders through the exercise of their police power;

(3) that only through adequate Federal control over interstate and foreign commerce in these weapons, and manufacturing, or dealing in them, can this grave problem be properly dealt with, and effective State and local regulation of this traffic be made possible;

.....

7 Feller \& Gotting, The Second Amendment: A Second Look, 61 Nw. U.L. Rev. 46 (1966); Hays, The Right to Bear Arms, A Siudy in Judicial Misinterpretation, 2 WM. \& MARY L. REv. 381 (1960); Levine \& Saxe, The Second Amendment: The Right to Bear Arms, 7 Hous. L. REv. 1 (1969); Mosk, Gun Control Legislation: Valid and Necessary, 14 N.Y.L.F. 695 (1968); Olds, supra note 4; Rohner, supra note 4; Sprecher, The Lost Amendment (pts. 1 \& 2), 51 A.B.A.J. 554, 665 (1965); Note, Constitutional Limitations on Fire. 
Thirty-five state constitutions, ${ }^{8}$ and the constitution proposed by the 1970 Illinois Constitutional Convention, ${ }^{9}$ guarantee a right to bear arms. However, the right is not absolute. Some of these provisions expressly authorize legislative control of firearms; $;^{10}$ and even in the absence of such specific authorization, the judiciary has long recognized that the exigencies of society require limits on the scope of the arms right. ${ }^{11}$ To analyze the impact of the various state arms provisions on firearms legislation, the comment first considers the sources and limits of state power to regulate arms in the absence of any such provision. It then delineates the purposes of particular state right to bear arms provisions and discusses whether familiar forms of gun control so frustrate these purposes as to be invalid. ${ }^{12}$

\section{Sources and Limits of State Power to Regulate Arms}

In the absence of specific constitutional authorization to regulate arms, the authority for such regulation stems solely from the general police power. The term "police power" refers to the general authority of state governments to enact legislation protecting or promoting the public health, safety, morals or general welfare. ${ }^{13}$ The range of legislation

arms Regulation, 1969 DUKE L.J. 773; Note, Constitutional Limitations on Federal Firearms Control, 8 WASHBURN L. REv. 238 (1969).

Earlier commentary includes:

Haight, The Right to Keep and Bear Arms, 2 Brus of Rugrrs Rev. 31 (1941); Note, The Constitutional Right to Keep and Bear Arms, 28 HARv. L. REv. 473 (1915). The only article which has emphasized the state arms provisions is McKenna, The Right to Keep and Bear Arms, 12 MARQ. L. REv. 138 (1928).

8 These provisions are cited and discussed in Part II infra. See text at notes $41-75$ infra. In addition to the thirty-five state constitutional provisions, New York protects the right to bear arms by statute. N.Y. Crv. RIGHTs LAw art. 2, $\$ 4$. The state arms provisions have been individually quoted in two articles: McKenna, The Right to Keep and Bear Arms, supra note 7, at 188 n.5; Rohner, supra note 4, at 80 .

- Sixth Illinois Constitutional Convention, Ill. Proposed Const. art. I, \& 22. The Convention convened on December 8, 1969 and adjourned on September 3, 1970. The proposed constitution will be submitted to the voters on December 15, 1970. Previous Illinois constitutions have not contained any arms-bearing provisions. If the constitution is adopted, section 22 would represent at least a political, if not a legal, advance for those opposed to gun control legislation. For a discussion of the provision adopted by the Convention see text at notes 64-66 infra.

10 These provisions are cited and discussed in text at notes 19-23 infra.

11 See discussion in Part III infra.

12 Since the state provisions are closely related to the second amendment, the analysis here would also be relevant to questions arising under that amendment.

13 See generally E. Freund, POLICE POWER (1904); Comment, Limiting the State's Police Power: Judicial Reaction to John Stuart Mill, 37 U. CHr. L. REv. 605 (1970). The notion of police power reflects the doctrine that, although the federal government is one of enumerated powers, the state governments generally have plenary authority to act except where restricted by their constitutions. See T.M. Cooley, Constitutional Limitations 9 (1871). 
permissible under the police power is restricted by the notion of reasonableness; both the goals of legislation and the means chosen to achieve those goals must be reasonable in light of the public welfare. ${ }^{14}$ State legislation is rarely invalidated on this basis, however, since courts usually defer to the legislative determination of the public welfare and presume the reasonableness of the means employed. ${ }^{15}$ In view of the limited uses and dangerous nature of firearms, even a law outlawing all possession would probably withstand the requirement of reasonableness. ${ }^{16}$ Thus, states without arms provisions, disregarding all other constitutional constraints, ${ }^{17}$ appear free to enact any of the familiar forms ${ }^{18}$ of firearms legislation under the general police power.

Authorization for gun control legislation in states with right to bear arms provisions stems either from the general police power or, in seventeen states, from clauses that qualify the arms provisions. These qualifying clauses either expressly authorize certain forms of regulation or impliedly approve such regulation. They range from narrow grants of power, ${ }^{19}$ such as those referring only to concealed weapons, to more gen-

14 For a listing of cases see, e.g., Comment, supra note 13, at 608 n.20.

15 The case most often quoted for this proposition is Jacobson v. Massachusetts, 197 U.S. 11, 31 (1905):

[U]pon what sound principles as to the relations existing between the different departments of government can the court review this action of the legislature? If there is any such power in the judiciary to review legislative action in respect of a matter affecting the general welfare, it can only be when that which the legislature has done comes within the rule that if a statute purporting to have been enacted to protect the public health, the public morals or the public safety, has no real or substantial relation to those objects, or is, beyond all question, a plain, palpable invasion of rights secured by the fundamental law, it is the duty of the courts to so adjudge, and thereby give effect to the Constitution.

See City of Akron v. Williams, 113 Ohio App. 293, 177 N.E.2d 802 (1960), rev'g 84 Ohio L. Abs. 490, 172 N.E.2d 28, rev'd on other grounds, 175 Ohio St. 186, 192 N.E.2d 63 (1963); Photos v. City of Toledo, 19 Ohio Misc. 147, 250 N.E.2d 916 (1969).

10 Since no state has yet wholly outlawed firearms, no holdings to this effect exist. However, there are some indications that such a statute would withstand attack in a state without a constitutional guarantee. See Ex parte Rameriz, 193 Cal. 633, 652, 226 P. 914, 922 (1924) ("[A]bsence of such a guarantee [right to bear arms in the state constitution] leaves the Legislature entirely free to deal with the subject.'); People v. Camperlingo, 69 Cal. App. 466, 231 P. 601 (1924). See also People v. McCloskey, 76 Cal. App. 227, 230, 244 P. 930, 931 (1926) ("No one can acquire a vested right to continue in possession of that which is a menace to the public."). Moreover, as the discussion in Comment, supra note 13, at 607, indicates, less menacing products than firearms have been banned by statute, e.g., intoxicating liquor and drugs.

17 E.g., due process, equal protection, self-incrimination, and the second amendment. The effects of these constraints are discussed in notes 1-4 supra.

18 The familiar forms of gun control legislation are discussed in Part III infra. The label "familiar" is intended to include both widely adopted forms of legislation and widely proposed forms of legislation.

19 Qualifying clauses that approve regulation of concealed weapons and prohibitions relating to unauthorized armed bodies of men fall within this description. The provisions relating to concealed weapons are: CoLo. Const. art. II, \& 13; KY. ConsT. Bill of Rights, \& 1; LA. Const. art. I, \& 8; Miss. Const. art. III, \& 12; Mo. Const. art. I, \& 28; 
eral authorizations which approach or equal the scope of the general police power. ${ }^{20}$ However, since these qualifying clauses neither expand ${ }^{21}$ nor constrict ${ }^{22}$ the scope of regulation permissible under the police power, they may be aptly characterized as manifestations of "superabundant caution," 23 and will receive little attention in this comment.

\section{Categorization of the State Arms Provisions}

The existing commentary concerning the arms right splits into two views. The "collectivists" 24 argue that maintenance of a strong militia

Mont. Const. art. III, \& 13; N.M. Const. art. II, § 6; N.C. ConsT. art. I, § 24. The provisions relating to unauthorized armed bodies of men are: ARIZ. CONST. art. II, $\$ 26$; WASH. CoNsT. art. I, § 24. Both the carrying of concealed weapons, and the organization of unauthorized armed bodies of men are practices that can be prohibited under the general police power even in the absence of express approval of such legislation. See text at notes 89 \& 93 infra.

20 Authorizations of regulation which approach or equal the scope of the police power are found in the following provisions: IDAHO CoNsT. art. I, \& 11 (regulation "of the right by law"); UtAH CONST. art. I, $\& 6$ (regulation "of the right by law"); TENN. CoNST. art. I, $\$ 26$ (regulation "with a view to prevent crime"); TEx. Const. art. I, \$23 (regulation "with a view to prevent crime"); FLA. Const. art. I, $\S 20$ (prescribing "the manner in which [arms] may be borne"); GA. CoNsT. art. I, \& 1, \& XXII (prescribing "the manner in which arms may be borne'). In addition, in the 1970 ILI. Proposed Const. art. I, § 22, the arms right is "subject only to the police power."

21 The limiting effect of the arms provisions on the police power will be fully discussed in Part III infra. That discussion of the forms of arms regulation permissible without reliance on an express authorization of regulation will make it apparent that these qualifying clauses do not expand the scope of regulation permissible under the police power.

22 For these clauses to limit the police power it would have to be ruled that, for example, where a clause gives authority to regulate concealed weapons, only that form of gun regulation is permissible. An old Tennessee case seems to embody that approach:

Under our constitution every citizen of the state has the right to keep and bear arms for his proper defense, and the Legislature only has power by law to regulate the wearing of arms to prevent crime.

State v. Foutch, 96 Tenn. 242, 247, 34 S.W. 1, 2 (1896). However, since state constitutions are restrictive, as opposed to enumerative, in nature, see note 13 supra, it seems unusual to give a positive grant of power such a restrictive effect. These positive grants of power are more likely to reflect specific evils which the drafters wanted to be certain would be subject to regulation under the police power. Such was the case in Kentucky where the concealed weapons clause was added in reaction to Bliss v. Commonwealth, $12 \mathrm{Ky}$. (2 Litt.) 90 (1822), which had overturned a statute outlawing concealed weapons. See note 82 infra. See State v. Gohl, 46 Wash. 408, 90 P. 259 (1907), for a clear indication that the positive grant of power to outlaw armed bodies of men does not impair the validity of other forms of regulation enacted under the police power. Another problem of interpretation is presented when the qualifying clause equals the scope of the general police power, as does the proposed Illinois clause, see note 20 supra. If the police power is interpreted as allowing a complete ban of weapons, then the qualifying clause would completely swallow the arms right it modifies. To avoid such nonsensical circularity, the qualifying clause must be interpreted as referring to regulations permissible under the police power as limited by the arms right. But this view renders the qualifying clause substantially meaningless, since all rights are, in that sense, "subject to the police power."

23 Haile v. State, 38 Ark. 564, 567 (1882) (referring to Tennessee constitution).

24 Feller \& Gotting, supra note 7; Mosk, supra note 7; Note, Constitutional Limitations 
was the primary purpose of the right and that the right therefore protects individuals only insofar as they are members of the protected group - the state militias. The "individualists," ${ }^{25}$ on the other hand, while agreeing that maintenance of militia was one purpose for establishing the right, argue that either deterrence of governmental oppression or self-defense ${ }^{26}$ was its ultimate purpose, thus guaranteeing private possession of weapons to all individuals.

To examine this controversy, this section considers the three purposes historically asserted for the arms guarantee and then categorizes the state constitutional provisions according to the purposes ostensibly served by each provision. In addition, this categorization is necessary to determine the scope of permissible arms regulation in states with arms provisions, a task undertaken in the third section of this comment.

\section{A. Purposes of a Right to Bear Arms}

In considering the three historical purposes ${ }^{27}$-maintenance of a militia, deterrence of governmental oppression, and self-defense-the judicial practice of examining contemporary circumstances ${ }^{28}$ as well as intentions of the drafters is followed.

1. Maintenance of Militias. Since the American Revolution, the desire to rely on citizen militias rather than on a centrally controlled standing army for protection against external and internal threats has been a justification for the right to bear arms. In post-Revolutionary America, reliance on state militias was a powerful impetus for protecting widespread possession of weapons. All capable men were members of the militia; its effectiveness depended upon their familiarity with firearms; and they used their own weapons when called to duty. ${ }^{29}$ Today, however,

on Firearms Regulation, supra note 7; Note, The Constitutional Right to Keep and Bear Arms, supra note 7; Note, Constitutional Limitations on Federal Firearms Control, supra note 7.

25 Hays, supra note 7; Levine \& Saxe, supra note 7; Olds, supra note 4; Rohner, supra note 4; Sprecher, supra note 7.

26 Rohner, supra note 4, at 73, states that interpreting the right for the purpose of self-defense is the only alternative to semanticism.

27 Legal commentary on the second amendment fully describes the historical foundations and development of these purposes and enables briefer discussion of each purpose and its underlying premises than would otherwise be necessary. See commentary cited in note 7 supra. In addition, several of the earlier cases give an exceptionally thorough explanation of the historical development of the arms right. These include: State v. Reid, 1 Ala. 612 (1840); Andrews v. State, 3 Tenn. 165 (1871); Aymette v. State, 21 Tenn. 154 (1840).

28 For instance, in Cases v. United States, 131 F.2d 916, 922 (1st Cir. 1942), the court criticized as outdated the Supreme Court's reference in United States v. Miller, 307 U.S. 174 (1939), to weapons constituting ordinary military equipment. The court referred to the contemporary use of all types of weapons by World War II commando units.

29 See United States v. Miller, 307 U.S. 154, 179 (1939); Haight, supra note 7, at 33; Feller \& Gotting, supra note 7, at 68 . 
only a relatively small proportion of able-bodied men are militia members (National Guardsmen). They are given formal training in the use of their weapons, which are issued by the government and which are often so exotic as to be unsuited for private possession. Thus, the maintenance-of-militia purpose no longer requires widespread possession of weapons, but remains a justification for arms possession only by militiamen in their official capacity. ${ }^{30}$

2. Deterrence of Oppression. The earliest justification for a right to bear arms was the desire to deter government from oppressing unarmed segments of the population. Thus, in reaction to the discriminatory disarming of Protestants by King James II, the English Bill of Rights of 1689 protected the right of Protestants to have arms for their defense. ${ }^{31}$ While no American constitutional language speaks specifically in terms of deterrence of governmental oppression, deterrence of oppression might well have been the ultimate purpose for relying on citizen militias. Reliance on militias, whose members possessed weapons in their private capacity, eliminated the tyrannical threat of a standing army while preserving the deterrent effect of an armed population against governmental oppression. ${ }^{32}$

However, continuing doubt as to whether deterrence of oppression actually was a purpose of the arms guarantee increases the significance of considering its contemporary viability. In the Revolutionary period the doctrine of deterrence of oppression was probably closely related to the controversial right of revolution. ${ }^{33}$ Because near equality then pre-

30 Feller \& Gotting, supra note 7, at 68. See also City of Salina v. Blaksley, 72 Kan. 230, 83 P. 619 (1905), the most famous of cases taking a collective view. See text at note 24 supra. The court states that the cases which justify an individual right on the ground that people should be familiar with weapons overlook the fact that the militia is drilled and trained. But cf. B. DAviDson, To KEEP AND BEAR ARMS (1969), which attributes our failure in Vietnam in large part to the poor marksmanship of American troops caused by unfamiliarity of the general citizenry with weapons. The Davidson book seems to have been written at least partly in response to C. BArAr, THE RIGHT to BEAR ARMS (1966), which takes a strong gun control stance.

31 See Feller \& Gotting, supra note 7, at 47-48.

32 Story was convinced of the deterrent effect of an armed population. See 2 STORY, COMMENTARIES ON THE CONSTITUTION 646 (1833):

The right of the citizens to keep and bear arms has justly been considered as the palladium of the liberties of a republic, since it offers a strong moral check against the usurpation and arbitrary power of rulers, and will generally, even if these are successful in the first instance, enable the people to resist and triumph over them.

Madison, in THE FEDERALIST No. 46, also intimated that a militia composed of citizens was necessary to prevent the development of tyrannical government. See Haight, supra note 7, at 33-34; Levine \& Saxe, supra note 7, at 10.

83 The New Hampshire State Constitution expressly recognized a right of revolution. N.H. ConsT. Bill of Rights, art. 10, concludes, "The doctrine of nonresistance against arbitrary power, and oppression, is absurd, slavish, and destructive of the good and happiness of mankind." See also J. Story, Commentaries on the Constitution 646 (1833). More recent commentators disagree. See R. Pound, The Deveropknent of Constrtutional Guar- 
vailed in the armaments of standing armies and the private arms of the people, an armed revolt could conceivably succeed. Today, in contrast, much modern weaponry is unsuited for private possession and near equality in armaments is unimaginable. ${ }^{34}$ It is thus difficult to conceive of a spontaneous armed revolt overthrowing the government. However, the potential for armed resistance remains as a restraining influence on oppressive governmental policies. ${ }^{35}$ To take an extreme case, a president might be tempted to declare himself dictator if he could effect such a change without bloodshed. But if he thought that imposition of a dictatorship would necessitate leveling America's cities to quash armed resistance, he might be content to remain merely a president. Thus, though the exact impact of an armed citizenry on governmental decisions is impossible to ascertain, ${ }^{36}$ private possession of weapons probably continues to have some restraining influence on governmental action.

3. Self-Defense. Self-defense, always a natural right at common law, ${ }^{37}$ did not emerge as a justification for the right to bear arms until its incorporation into several state arms provisions. ${ }^{38}$ Though self-defense

ANTEES OF LIBERTY 90-91 (1957): "In the urban industrial society of today a general right to bear efficient arms so as to be enabled to resist oppression by the government would mean that gangs could exercise an extra-legal rule which would defeat the whole Bill of Rights." Though he concedes the right to revolution is a moral right, Pound does not view it as a right entitled to legal recognition. See also Dennis v. United States, 341 U.S. 494, 501 (1951) ("Whatever theoretical merit there may be to the argument that there is a 'right' to rebellion against dictatorial governments is without force where the existing structure of the government provides for peaccful and orderly change.').

34 See discussion in text at notes 100-03 infra.

35 There are some contemporary examples of instances where the presence of arms among the population at large seems to have had the effect of deterring governmental oppression without resort to actual rebellion. For instance, there is some indication that police and organized white oppression of blacks has decreased in the South because of the burgeoning possession of firearms by blacks. See N.Y. Times, Aug. 13, 1970, at 20; Johnson, Decade of Change in South Gives Negroes High Hopes, N.Y. Times, Aug. 16, 1970, at 1 \& 54.

so Compare Story's view of 1833, supra note 32, with Pound's view of 1957, supra note 33. See also Washington, Panther Parley Winds Up with Demands to Society, Chicago SunTimes, Sept. 8, 1970, at 18. The recently held Black Panther convention in Philadelphia, which discussed "radical" constitutional reform, placed some emphasis on the oppressive tendencies of well-armed police forces and standing armies and the need for common citizens to be armed for the defense of society-views which are strikingly similar to those of Story, supra note 32. More perplexing than whether a potential for armed resistance has any impact on the decision-making process is the extent to which its influence has been supplanted by a potential for massive unarmed dissent. See generally A. HARE \& H. Blumberg, Nonviolent Direct Action (1968). However, it seems safe to conclude that even the increased impact of nonviolent dissent in an industrial society has not rendered a potential for armed dissent wholly superfluous.

37 Nunn v. Georgia, 1 Ga. 241, 251 (1846). See also 4 W. Blackstone, Commentaries *182-184; 3 id. *4: "Self-defense, therefore, as it is justly called the primary law of nature, so it is not, neither can it be in fact, taken away by the law of society." I id. "130 (1765). 38 See text at notes:45-75. Blackstone did recognize the relation between possession of 
does not appear to include use of weapons for purposes such as hunting for food, its emergence as an arms justification probably reflects the uniquely American frontier experience. ${ }^{39}$ Self-defense continues as a justification for private possession of weapons, though now that people no longer depend upon guns for day-to-day survival, ${ }^{40}$ the level of danger at which self-defense becomes a realistic justification of arms possession seems unclear.

\section{B. Classification of State Arms Provisions}

State court opinions concerning the right to bear arms rarely refer to the specific language of their constitutions, and they often cite the provisions and court decisions of other states without noting differences in language and emphasis. ${ }^{41}$ One reason for these practices may be that in the absence of gun control legislation raising difficult questions under the arms provisions ${ }^{42}$ slight textual differences have been unimportant. A second reason for the unsophisticated analyses in this field may be the failure of any commentator to categorize the provisions and draw meaningful distinctions between categories. ${ }^{43}$ That task is attempted here.

While there are numerous textual differences among the right to bear arms provisions, ${ }^{44}$ the construction of these provisions turns pri-

arms and self-defense. I W. BLACKsToNE, supra note 37 , at *144, but only "such as were allowed by law," and the law of England greatly circumscribed any right to keep arms. See Rohner, supra note 4 , at 62.

30 See Matthews v. State, 237 Ind. 677, 689-92, 148 N.E.2d 334, 339-41 (1958) (dissenting opinion).

40 The continued resilience of opinion advocating the necessity of an arms right irrespective of the need of guns for survival might reflect certain male psychological characteristics. See C. BAKaL, supra note 30, at 86-92 (1966). In the opening chapter of THE REIVERS (1962), William Faulkner sketches a character who displays the tendency of many men to rely on firearms as symbols of manhood.

41 See, e.g., Carlton v. State, 68 Fla. 1, 9, 58 So. 486, 488 (1912) (citing a West Virginia case and Presser v. Illinois, 116 U.S. 252 (1886), both of which interpret the second amendment); City of Salina v. Blaksley, 72 Kan. 230, 233, 83 P. 619, 620 (1905) (citing a Massachusetts decision); State v. Robinson, 217 Ore. 612, 617-18, 343 P.2d 886, 889 (1959) (citing California cases and noting decisions reported in Annot., 24 A.L.R. 1119 (1923)); Ex parte Thomas, 21 Okla. 770, 774, 97 P. 260, 262 (1908) (citing Tennessee, Georgia and Kansas decisions).

42 See Feller \& Gotting, supra note 7, and other authorities cited therein which make similar observations. BARAL, supra note 30 , at ch. 7, devotes a full chapter to describing the lobbying efforts of the National Rifle Association which have been notably successful in preventing the adoption of gun control laws, both at the federal and local levels.

43 McKenna, supra note 7, at 140-42, does list some of the differences among the provisions but makes little effort to determine whether these differences have any impact.

44 There are three differences among the arms provisions which seem to have little effect on the scope of the right. First, some of the provisions guaranteeing a right to bear arms accrue to the benefit of all "people" ("persons" or "men"), while the others refer only to "citizens," thus not including aliens within their purview. Examples of 
marily on two factors: (1) whether those to whom the right is granted are referred to in the plural or in the singular, and (2) the purpose for

those including aliens within their protection are: FLA. CONST. Declaration of Rights, § 20 ("people"); Colo. Const. art. II, \& 13 ("person"); Ky. Const. Bill of Rights, \$ 1 (the only provision using "men"). The arms provisions of the following states refer only to "citizens": ALA. Const. art. I, § 26; ARIZ. CONST. art. II, § 26; ARK. CoNST. art. II, § 5; Conn. Consr. art. I, § I5; MIss. Const. art. III, § 12; Mo. Const. art. I, § 23; OKIA. CONST. art. II, § 26; PA. CONST. art. II, § 21; S.D. ConST. art. VI, § 24; TEX. ConST. art. I, § 23; TENN. CoNST. art. I, § 26; WASH. Const. art. I, § 24; WYo. CoNST. art. I, § 24. Many cases have upheld statutes denying aliens the right to possess weapons on the basis of this difference. See Commonwealth v. Patsone, 231 Pa. 46, 79 A. 928 (1911), aff'd, 232 U.S. 138 (1914) (statute preventing aliens from possessing rifles and shotguns upheld as valid exercise of police power for protection of wild game of state). Other cases are cited in Annot., 24 A.L.R. 1119 (1923). While these statutes are phrased as "game laws," since the time of Blackstone that has been recognized as a euphemism under which restrictive gun control statutes have been enacted. 2 BLACKSTONE, supra note 37, at *412. However, the present day validity of these cases and of the arms provisions themselves, which seek to limit the right to citizens, might be questioned under the equal protection clause, especially when the right is granted for the non-political purpose of selfdefense. See note 1 supra. See also the results reached in the following instances in states where the arms right inures to all people: People v. Zerillo, 219 Mich. 635, 189 N.W. 927 (1922) (statute overturned because arms right inures to all people). Commonwealth v. Patsone, supra, was distinguished in Zerillo because of the people/citizen difference in the arms right of the respective states. People v. Nakamura, 99 Colo. 262, 62 P.2d 246 (1936), citing Zerillo, reached the same result.

The second difference having little substantive impact is that some of the provisions insure a right only to "bear" arms while others involve a right to "keep and bear" arms. The following provisions use only "bear": ALA. Const. art I, \& 26; ARIz. Const. art. II, § 26; ConN. Const. art. I, § 15; WASH. Const. art. I, § 24; FLA. Const. art. I, § 20; IND. Const. art. I, § 32; KY. Const. Bill of Rights, § 1; ORE. Const. art. I, § 27; PA. Const. art. II, § 21; S.D. Const. art. VI, § 24; VT. Consr. ch. I, art. 16; Wyo. Const. art. I, § 24. All other provisions use the "keep and bear" form. They are cited in notes $45-75$ infra. The difference between "bear" and "keep and bear" could conceivably affect a court's choice of the collective or individual theory in view of some intimations that "bear" does not include the right personally to possess weapons in a non-military capacity. E.g., Ex parte Thomas, 21 Okla. 770, 97 P. 260 (1908); Aymette v. State, 21 Tenn. 154, 158 (1840). But the courts seem to have given no effect to this difference, a happy abstention from nit-picking. However, the fact that the verbs "bear" or "keep and bear" have been used, as opposed to other verbs of broader scope, has had some impact in situations not deemed to come within the scope of either form of verb. See, e.g., State v. Duranleau, - Vt. -, 260 A.2d 383 (1969) (loaded weapon).

The third difference having little operative significance is that several provisions have additional clauses referring to the danger to liberty of standing armies and the need to keep military power subordinate to civil authority. See KAN. CoNST. Bill of Rights, § 4; MASs. Const. pt. 1, art. XVII; N.C. Const. art. I, § 24; OHIo Const. art. I, § 4; ORE. ConsT. art. VI, § 27; Vr. CoNST. ch. I, art. 16. While these clauses strengthen the conclusion that these provisions have maintenance of a strong militia as one purpose, that purpose is accepted as one purpose of these state constitutional provisions without reference to the clauses. See chart at note 75 infra. Moreover, the clauses do not preclude other purposes. In addition, other state constitutions have similar clauses calling for subordination of the military and criticizing standing armies, but these clauses are separated from the arms provisions. E.g., DEL. Const. art. I, \& 17; ILL. CoNsT. art. II, § 15; PA. Const. art. I, $\S 22$. 
which the right is granted. The purpose of a provision might affect the types of weapons protected and the validity of certain forms of regulation. In addition, the purpose aids in determining whether the right is collective or individual. If the purpose is either self-defense or deterrence of oppression, the right seems to protect private possession of weapons, since only through private possession can those purposes be fulfilled. Only when the purpose is limited to reliance on militia is it possible to adopt a collective interpretation guaranteeing the right to only members of the militia.

The use of a plural noun reinforces a collective interpretation by indicating that the right might not inure to particular individuals. Thus, a combination of plural noun with militia purpose results in a collective right. If the noun is singular, however, private possession is protected even if the sole purpose is reliance on militia. These general propositions are demonstrated in the following categorization of the arms provisions, which seeks to determine whether each category of provisions protects private possession.

1. Plural Subjects.

(a) Second amendment pattern. Five states ${ }^{45}$ have provisions identical to the second amendment of the United States Constitution:

A well regulated Militia, being necessary to the security of a free State, the right of the people to keep and bear Arms, shall not be infringed.

One purpose obvious on the face of these provisions is reliance on state militias. ${ }^{46}$ As such, they establish collective rights not protecting private possession. However, as previously discussed, ${ }^{\mathbf{4 7}}$ these provisions may also reflect a desire to deter oppression, ${ }^{48}$ thus justifying private possession.

(b) "People ... not Infringed." Two states, Georgia ${ }^{49}$ and Rhode Island, ${ }^{, 0}$ have provisions that repeat the main clause of the second

45 ALAs. Const. art. I, § 19; HAwaII Const. art. I, $\S 15$; LA. Const. art. I, $\S 8$; N.C. Const. art. I, § 24; S.C. ConsT. art. I, § 26.

40 See United States v. Miller, 307 U.S. 174 (1939) (construing second amendment); Brown v. City of Chicago, 42 IIl. 2d 501, 504, 250 N.E.2d 129, 131 (1969) ("regulation which does not impair maintenance of the state's active organized militia is not in violation of either the terms or the purpose of the second amendment"); State v. Dawson, 272 N.C. 535 , 159 S.E.2d I (1968); State v. Kerner, 181 N.C. 574, 107 S.E. 222 (1921).

47 See text at notes $31-36$ supra.

48 This view was taken in State v. Kerner, 181 N.C. 574, 577, 107 S.E. 222, 224 (1921) (private possession of arms necessary to prevent usurpation of illegal power). But see State v. Dawson, 272 N.C. 535, 546, 159 S.E.2d 1, 9 (1968) (relates constitutional right to bear arms to common law right of self-defense).

$49 \mathrm{GA}$. Const. art. I, \& 1.

so R.I. CoNsT. art. I, $\$ 22$. 
amendment, "the right of the people to keep and bear arms shall not be infringed," but omit the introductory reference to the militia. Because of this omission, the language of these provisions does not refer specifically to any purpose. They might thus embody any or all of the three historical purposes. ${ }^{51}$

(c) "People ... for the Common Defense." Three states ${ }^{62}$ have provisions affirming the right of the citizens or people "to keep and bear arms for the [or their] common defense." These provisions reflect the militia justification. ${ }^{53}$ In addition, since the "common defense" need not be identical with defense of the state, they probably also recognize deterrence of oppression as a purpose. ${ }^{54}$ Thus, these provisions probably justify private possession.

(d) "People ... for their Security and Defense." Five states ${ }^{55}$ have provisions which state that the "people have the right to bear arms for their security and defense." These provisions are ambiguous because of the difficulty of determining whether "their" is used in an individual or in a collective sense. Looking only to the language of the provisions, it is thus possible to construe them as relating to any or all of the three purposes. The reference to "security" seems to include at least reliance on militia as a purpose. It might also refer to deterrence of oppression since the people's security might not always coincide with the security of the state. In addition, all five states have constitutional search and seizure provisions identical to the fourth amendment of the federal Constitution using "their" and "the people" in an individual sense. ${ }^{56}$ That individual usage suggests that the similarly phrased arms

51 Georgia has construed its provision as being governed by the scope of the second amendment because of historical considerations. At one time, the Georgia arms provision was identical to the second amendment. Thus, Hill v. Georgia, 53 Ga. 472 (1874), naturally concluded that that provision was governed by the scope of the second amendment. This view was adhered to even after the militia reference was deleted. See Strickland v. State, 137 Ga. 1, 72 S.E. 260 (1911). Georgia, however, recognizes the natural right of self-defense as protecting private possession of weapons, though it is not clear whether it deems such possession to be constitutionally protected. See Nunn v. Georgia, 1 Ga. 243 (1846).

62 ARR. CONST. art. II, § 5 ("citizens"); MAss. CONST. Deciaration of Rights, pt. I., art. XVII ("people"); TENN. Const. art. I, \& 26 ("citizens").

53 This view was adopted in: Fife v. State, 31 Ark. 455 (1876); Andrews v. State, 50 Tenn. 165 (1871).

54 This opinion was expressed in: Fife v. State, 31 Ark. 455 (1876); Andrews v. State, 50 Tenn. 165 (1871); Aymette v. State, 21 Tenn. 154 (1840). See also Heaton v. State, 130 Tenn. 163, 169 S.W. 750 (1914) (implying constitutional protection of arms possession for right of self-defense).

55 IDAHO Const. art. I, § Il; KAN. CoNST. Bill of Rights, § 4; N.M. CoNST. art. II, \& 6; OHo Const. art. I, § 4; UTAH CONST. art. I, § 6.

5o IDAHo Const. art. I, § 17; KAN. Const. Bill of Rights, § 15; N.M. Const. art. II, 
provisions also express an individual right. Guaranteeing arms possession for the "defense" of individuals implies self-defense as another purpose of the provisions. ${ }^{57}$

(e) "People . . . for Defense of Themselves and the State." Eight states $^{68}$ have provisions which state that the people (citizens or all men) have the right to bear arms in defense of themselves and the state. These provisions, by reference to "defense of the state," clearly entail maintenance of militia as one purpose. ${ }^{59}$ That is their only purpose only if "themselves" is read as synonymous with "state," a strained construction since it renders "themselves" redundant. The more reasonable construction is that "themselves" refers either to the people as a collective body apart from the existence of the state (reflecting deterrence of oppression), ${ }^{60}$ or to each individual person (reflecting self-defense), or to both. A choice between these alternatives cannot be made on the basis of the language itself. However, in Kentucky and Vermont independent reasons appear for adopting the individual self-defense purpose. In Kentucky the subject "all men" is not contained in the arms provision itself, but appears in an introductory phrase pre-

§ 10; OHIo CoNST. art. I, § 14; UTAF CoNST. art. I, § 14. These provisions are all worded to the same effect as the Idaho constitution:

The right of the people to be secure in their persons, houses, papers, and effects, against unreasonable searches and seizures, shall not be violated ....

Without question they refer to the houses, papers, etc. of individual people.

67 For cases suggesting self-defense as a purpose, see In re Brickley, 8 Idaho 597, 70 P. 609 (1902) (overturns statute preventing carrying of deadly weapons within city limits, thus protecting private possession). See also Lopez v. Chewiwie, 51 N.M. 421, 186 P.2d 512 (1947) (In a tort action brought against parent who had left son unattended with a rifle at home, court refused to hold parent liable for killing of plaintiff's intestate. The court cited the state constitutional arms provision and a statute as representing state policy of allowing guns in the home.). Cf. City of Salina v. Blaksley, 72 Kan. 230, 83 P. 619 (1905) (This is the most noted of decisions which take a collective view. See note 30 supra. However, the conviction it upheld, carrying of a pistol within city limits while intoxicated, could have been upheld under the police power even if the arms right were individual. Thus, in a sense, the "collective" characterization is dictum.). However, the Kansas court seems adamant in its view. See State v. Bolin, 200 Kan. 369, 436 P.2d 978 (1968) (reiterating collective theory in upholding statute prohibiting possession of pistols by convicted felons, a statute which also could have been upheld if the right were individual).

58 FLA. Const. Declaration of Rights, $\S 20$ ("people"); IND. Const. art. I, $\S 32$ ("people"); KY. Const. Bill of Rights, \& 1 ("all men"); ORE. Consr. art. I, § 27 ("people"); PA. CoNST. art. I, § 21 ("citizens"); S.D. CoNsT. art. VI, § 24 ("citizens"); Vr. CoNST. ch. I, art. 16 ("people"); Wyo. Const. art. I, \& 24 ("citizens").

59 This view is taken in Nelson v. State, 195 So. $2 d 853$ (Fla. 1967) (noting similarity to militia-oriented second amendment).

6o One case has adopted this interpretation. Carlton v. State, 63 Fla. 1, 58 So. 486 (1912). 
ceding a listing of "inalienable rights." 61 Except for the right to bear arms, the rights enumerated, such as free speech, are clearly individual. Thus, the right to bear arms would likewise seem to be individual. In Vermont, the similarly phrased search and seizure provision ${ }^{62}$ uses "themselves" in an individual sense, thus implying self-defense as a purpose. ${ }^{83}$

2. Singular Subjects.

(a) "Citizen ... not Infringed." The document proposed by the Sixth Illinois Constitutional Convention contains an arms provision that states:

Subject only to the police power, the right of the individual citizen to keep and bear arms shall not be infringed. ${ }^{64}$

This provision contains no expression of purpose to assist interpretation. Its use of a singular subject, however, indicates a desire to protect private possession. Since reliance on a militia no longer justifies private possession, ${ }^{65}$ it thus seems unsound to restrict this recently drafted provision to that purpose alone. A rigid historical analysis would then recommend relating it to deterrence of oppression, or self-defense, or both, though it is unlikely that the delegates considered deterrence of oppression. ${ }^{68}$

(b) "Citizen . . . for Common Defense." One state, Maine, ${ }^{67}$ guarantees "every citizen the right to keep and bear arms for the common defense." As previously indicated, ${ }^{68}$ the common defense definitely reflects the militia rationale and probably entails deterrence of oppression as well. If this provision used a plural noun, it might be plausible to argue that it should be restricted to the militia rationale, and as such should not justify private possession. However, even if this provision

$61 \mathrm{Kr}$. Const. Bill of Rights, § 1 .

62 VT. ConsT. ch. I, art. 11.

63 This conclusion is reached in State v. Rosenthal, 75 Vt. 295, 55 A. 610 (1903) (citing constitution as protecting possession for self-defense). Indiana also supports the selfdefense view. Matthews v. State, 237 Ind. 677, 148 N.E.2d 334 (1958).

64 Ill. Proposed Const. art. I, § 22.

65 See text at notes 29-30 supra.

66 RePort of the Commitre on BiLl of Rights to the Convention \& 27, at 4 (May 22, 1970) contains a short memorandum describing arms provisions in other states, and contrasting their construction with the construction likely to be given to the proposed arms provision. It states:

The substance of the right is that a citizen has the right to possess and make reasonable use of arms that law-abiding persons commonly employ for purposes of recreation or of protection of person and property. (Emphasis added.)

Nowhere is there an indication that deterrence of oppression was a purpose for guaranteeing the right to bear arms.

o7 ME. ConsT. art. I, \$ 16.

o8 See text at notes 52-54 stupra. 
were limited to reliance on militia, the right would not seem limited to only those actually participating in militia activities. By using "every citizen" instead of a plural noun it seems to protect private possession in case the need should ever arise for private individuals to use weapons in the militia-as unlikely as that eventuality may now be. ${ }^{69}$ Thus, even though it is not certain that this provision reflects deterrence of oppression, ${ }^{70}$ the provision, due to the singular noun, definitely protects private possession of weapons.

(c) "Person ... for Defense of Himself and State." Six states"1 have provisions upholding the right of every citizen or person to bear arms in defense of himself and the state. Reliance on militia and self-defense are both reflected in these provisions. ${ }^{72}$ Moreover, these provisions seem limited to those two purposes. By referring only to defense of "state," they seem to preclude deterrence of oppression as a purpose.

(d) "Person ... in defense of his Home, Person and Property or the Civil Power." Five states ${ }^{73}$ promise every citizen or person the right "to keep and bear arms in defense of his home, person and property, or in

69 This point might best be seen by comparing the implications of two hypothetical provisions.

Example A

Those people who are in the militia may keep and bear arms for use in the militia.

Example B

Each person may keep and bear arms for use in the militia.

Example $A$ is a clear statement of the collective view of the right. Under such a provision, a person not in the militia would not have a right to bear arms. On the other hand, Example B seems to imply that each person may keep arms irrespective of his relation to the militia because of a possibility foreseen by the drafters that the occasion might arise when each person would use arms for the protected purpose. They have a right to keep arms in case that occasion should arise. The provision under discussion seems to fall within Example B.

70 The Maine Supreme Court, by way of interpretation, has indicated but not held that possession of firearms for hunting is not constitutionally protected. State v. McKinnon, 153 Me. 15, 133 A.2d 885 (1957). See cases cited in note 54 stcpra which, while interpreting provisions using a plural noun, construe "common defense" as relating to deterrence of oppression.

71 Ala. Const. art. I, § 26 ("citizen"); ARIz. CONST. art. II, § 26 ("citizen"); ConN. CoNST. art. I, § 15 ("citizen"); Mrch. ConsT. art. I, \$6 ("person") (When the 1909 Michigan constitution was replaced with the present 1964 constitution, "keep" was added, so that the right preserved is "to keep and bear." This change supports the contention that constitutional protection of the arms right is becoming more extensive as new constitutions are adopted. See note 9 supra.); Tex. Const. art. I, \$ 23 (The provision uses the "keep and bear" format also. It also falls in the "citizen" category.); WASH. CONST. art. I, \& 24 ("citizen").

72 For cases reaching this conclusion, see People v. Brown, 253 Mich. 537, 235 N.W. 245 (1931); People v. Zerillo, 219 Mich. 686, 189 N.W. 927 (1922); State v. Duke, 42 Tex. 455 (1875); Jennings v. State, 5 Tex. Ct. App. R. 298 (1878). Compare Galloway v. State, 125 Tex. Crim. 524, 69 S.W.2d 89 (1933) (hunting not protected).

73 Cozo. Const. art. II, $\$ 13$ ("person"); Miss. Const. art. III, $\$ 12$ ("citizen"); Mo. CoNsT. art. I, § 23 ("citizen"); MoNT. CoNst. art. III, \& 13 ("person"); OKLA. CoNst. art. II, $\S 26$ ("citizen"). 
aid of the civil power when thereto legally summoned." Reliance on militia and self-defense are evident in these provisions. ${ }^{74}$ They represent broad statements of the self-defense function by approving defense of home and property as well as person. They do not entail deterrence of oppression, however, since they limit defense of the state to instances when an individual is legally summoned.

\section{G. Summary}

The above analysis yields the conclusions summarized in the chart categorizing the arms provisions. ${ }^{75}$

\section{Extent to Which State Arms Provisions Limit the Range of Permissible Gun Control Legislation}

As discussed above, ${ }^{76}$ disregarding all constitutional constraints other than those imposed by state arms provisions, ${ }^{77}$ states without such provisions appear free to adopt any of the familiar forms of gun control legislation, including mandatory registration, regulation of vendors, and absolute prohibition of all arms. ${ }^{78}$ However, the boundaries of permissible arms regulation remain undetermined in those states with arms provisions. At one extreme, it is clear that legislation banning all

74 This conclusion is reached in: People v. Nakamura, 99 Colo. 262, 62 P.2d 246 (1936); Patterson v. State, 251 Miss. 565, 170 So. 2d 635 (1965); State v. Plassard, 355 Mo. 90, 195 S.W.2d 495 (1946); State v. White, 299 Mo. 599, 253 S.W. 724 (1923); State v. Nickerson, 126 Mont. 157, 247 P.2d 188 (1952); State v. Rathbone, 110 Mont. 225, 100 P.2d 86 (1940).

75 The provisions are cited in the following notes supra: 45,49 and $50,52,55,58,64,67$, $71, \&$ 73. These notes are listed in the same order that the provisions appear in the chart.

76 See text at notes $13-18$ supra.

77 See note 17 supra.

78 This section is not intended to be an exhaustive listing of state gun control statutes or an evaluation of their effectiveness. For charts listing and categorizing the state statutes see: American Bar Foundation Research Staff, Firearms and Legislative ReguLATION App. B, at 12 (1967); BAKAL, supra note 30, App. II, at 346; NATIONAL RIFLE AsSOCIATION HANDBOOK: FIREARMS LAWS AND COURT Decisions $82-83$ (1965); NewTon \& ZimRING, supra note 1, at 92-93 \& App. G, at 201. Discussion of the general forms of firearms regulation is found in: Newron \& ZIMRING, supra note 1, at 82-85; Brabner \& Smith, Firearm Regulation, 1 LAw \& ConTEMP. Prob. 400 (1934). More detailed analysis of gun control provisions is found in: NEwTON \& ZIMRING, supra note 1, at 87-111; Note, Firearms: Problems of Control, 80 HARv. L. REv. 1328 (1967); Note, Firearms Legislation, 18 VAND. L. REv. 1362 (1965). See also Comment, Federal Regulation of Firearm Sales, 31 U. CHI. L. REv. 780 (1964); Note, Restrictions on the Right to Bear Arms: State and Federal Firearms Legislation, 98 U. PA. L. REv. 905 (1950). Most of the above sources address the constitutional issues raised by right to bear arms provisions, but not with the depth of analysis attempted in this section. Moreover, none of them focuses on the state constitutional provisions and the impact on gun legislation, if any, of differences in these provisions. 


\section{Categorization of Arms Provisions}

\begin{tabular}{|c|c|c|c|c|c|c|}
\hline $\begin{array}{l}\text { Number } \\
\text { of Noun }\end{array}$ & $\begin{array}{c}\text { Stated } \\
\text { Purpose }\end{array}$ & States & $\begin{array}{c}\text { Reliance } \\
\text { Militia }\end{array}$ & $\begin{array}{l}\text { Deterrence } \\
\text { Oppression }\end{array}$ & $\begin{array}{c}\text { Self- } \\
\text { Defense }\end{array}$ & $\begin{array}{l}\text { Private } \\
\text { Possession }\end{array}$ \\
\hline & $\begin{array}{l}\text { militia } \\
\text { reference }\end{array}$ & 5 & yes & possibly & no & possibly \\
\hline & none & 2 & possibly & possibly & possibly & probably* \\
\hline & $\begin{array}{l}\text { common } \\
\text { defense }\end{array}$ & 8 & yes & probably & no & probably \\
\hline \multicolumn{7}{|l|}{ Plural } \\
\hline & $\begin{array}{l}\text { their defense } \\
\text { and security }\end{array}$ & $\mathbf{5}$ & yes & possibly & probably & probably* \\
\hline & $\begin{array}{l}\text { defense of } \\
\text { themselves } \\
\text { and state }\end{array}$ & 8 & yes & possibly & probably & yes** \\
\hline
\end{tabular}

$\begin{array}{ccccccc}\text { none } & \text { 1a } & \text { possibly } & \text { possibly } & \text { possibly } & \text { yes*** } \\ \begin{array}{c}\text { common } \\ \text { defense }\end{array} & 1 & \text { yes } & \text { probably } & \text { no } & \text { yes*** } \\ \text { Singular } & \begin{array}{c}\text { defense of him- } \\ \text { self and state }\end{array} & 6 & \text { yes } & \text { no } & \text { yes } & \text { yes } \\ \begin{array}{c}\text { defense of his } \\ \text { home, person, } \\ \text { property and } \\ \text { civil power }\end{array} & 5 & \text { yes } & \text { no } & \text { yes } & \text { yes } \\ & & & & & \end{array}$

- For these provisions, the likelihood that private possession is protected is somewhat greater than the likelihood that either deterrence of oppression or self-defense is a purpose because both of those purposes justify private possession. Where possible, this mathematical factor is reflected in the private possession column.

** These provisions definitely protect private possession because they reflect at least one, though it is not certain which one, of the two purposes justifying private possession.

*** Because a singular noun is used, these provisions protect private possession even though it is not certain that they entail purposes that justify private possession.

2 This is the proposed Illinois provision. See text at notes 64-66 supra. 
arms is forbidden in the twenty states ${ }^{79}$ whose constitutions definitely protect private possession; ${ }^{80}$ and a similar result is likely in states whose constitutions probably protect private possession. ${ }^{81}$ But determining that a complete ban on weapons is impermissible is only the threshold from which to begin consideration of the permissibility of less extreme forms of gun control. It is with this problem of degree that this section wrestles. ${ }^{82}$

The scope of permissible regulation in states with arms provisions is dependent upon a balancing ${ }^{83}$ of the public benefit to be derived

79 See chart at note 75 supra, especially entries where private possession column is marked "yes."

80 See People v. Nakamura, 99 Colo. 262, 62 P.2d 246 (1936) (aliens cannot be disarmed); People v. Brown, 253 Mich. 537, 235 N.W. 245 (1931) (upholding conviction for possession of blackjack, but cautioning that state cannot ban weapons normally viewed as legitimate for protection of person and property); People v. Zerillo, 219 Mich. 636, 189 N.W. 927 (1922) (possession of revolver for legitimate self-defense cannot be a crime); Jennings v. State, 5 Tex. Ct. App. R. 298 (1878) (law calling for forfeiture of improperly carried weapons struck down).

81 See chart at note 75 supra, especially entries where private possession column is marked "probably." For decisions upholding private possession, see: In re Brickley, 8 Idaho 597, 70 P. 609 (1902) (legislature cannot prohibit carrying of weapons in any part of state); Glasscock v. City of Chattanooga, 157 Tenn. 518, 11 S.W.2d 678 (1928) (cannot forbid open carrying of army and navy pistols); Smith v. Ishenhour, 43 Tenn. 214 (1866) (statute passed by secessionist state government during Civil War calling for collection of private arms held unconstitutional); State v. Rosenthal, 75 Vt. 295, 55 A. 610 (1903) (city ordinance barring the carrying of pistols without permission of mayor struck down). But cf. City of Salina v. Blaksley, 72 Kan. 230, 83 P. 619 (1905) (decision takes a strong collective view of right and might imply that statute banning all private possession would be upheld).

82 The proposition that the right embodied in a constitutional arms provision is absolute, precluding adoption of any regulation of arms whatsoever, was adopted in one case. Bliss v. Commonwealth, $12 \mathrm{Ky}$. (2 Litt.) 90 (1822). It is cited today only to reject its rigid reasoning. The court struck down a law banning the carrying of concealed weapons. It reasoned as follows: The same rationalization that would uphold a concealed weapons statute as only a regulation, and not a destruction of the right, would likewise uphold a statute prohibiting nonconcealed weapons. Yet both statutes cannot be constitutional, since to uphold both would totally destroy the right. Therefore, the court concluded that neither form of statute could stand. That reasoning can be applied to any regulation of arms and therefore leads to holding the right absolute. Notably, Kentucky has since added to its constitution a specific authorization for the legislature to outlaw the carrying of concealed weapons. KY. CoNsT. Bill of Rights, \& I. The case law has uniformly rejected the reasoning in Bliss. E.g., State v. Reid, 1 Ala. 612 (1840) (upholding a concealed weapons statute, but stating that carrying nonconcealed weapons, being a lesser evil, could not be barred while a concealed weapons statute was on the books).

83 See State v. Rathbone, 110 Mont. 225, 100 P.2d 86, 92 (1940):

The result of the operation of the police power is necessarily in most instances an infringement of private rights, but in the exercise of such power, property and individual rights may be injured or impaired only to the extent reasonably necessary to preserve the public welfare.

See also State v. Dawson, 272 N.C. 535, 548, 159 S.E.2d 1, 11 (1968); State v. Gohl, 46 Wash. 408, 90 P. 259 (1907). Dawson and Gohl state that a constitutional guarantee of rights does not place the exercise of these rights beyond the police power, observing that 
from the regulation against the degree to which it frustrates the purposes of the provision. ${ }^{84}$ The purposes to be considered are those that justify private possession:85 deterrence of oppression ${ }^{86}$ and self-defense. ${ }^{87}$ This section examines the extent to which familiar forms of arms regulation frustrate these purposes.

\section{A. Place and Manner Laws}

A wide variety of laws restricts the place and manner in which firearms may be carried. Statutes and ordinances ${ }^{88}$ forbidding such practices as carrying concealed weapons, ${ }^{80}$ carrying pistols within city limits $^{90}$ or in a courtroom, ${ }^{91}$ carrying loaded weapons, ${ }^{92}$ and drilling of

freedom of speech and press do not protect libel, slander, or shouts of fire in a crowded theatre. Another example of the balancing approach is Cases v. United States, 13I F.2d 916, 922 (1st Cir. 1942) (stating that it is "impossible to formulate any general test by which to determine the limits imposed by the Second Amendment but that each case under it, like cases under the due process clause, must be decided on its own facts").

The one caveat to this balancing approach is that legislation cannot wholly destroy the right regardless of the benefit. Total destruction of the right can be accomplished only through the amending process. See State v. Reid, 1 Ala. 612, 616 (1840) ("A statute which, under the pretense of regulating, amounts to a destruction of the right, or which requires arms to be so borne as to render them wholly useless for the purpose of defense, would be clearly unconstitutional.'). See also People v. Brown, 253 Mich. 537, 235 N.W. 245 (1931), and authorities cited note 15 supra.

84 See, e.g., United States v. Miller, 307 U.S. 174 (1939); Cases v. United States, 131 F.2d 916 (1st Cir. 1942); United States v. Tot, 131 F.2d 261 (3d Cir. 1942), rev'd on other grounds, 319 U.S. 463 (1943); Brown v. City of Chicago, 42 Ill. 2d 501, 250 N.E.2d I29 (1969). All these cases uphold, under the second amendment, regulation which does not impair what the courts deem the purpose of that amendment-maintenance of the states' active militias.

85 Where a provision uses a singular noun, private possession is probably protected even if militia reliance is the only purpose. See text at notes 68-70 supra. But since militia reliance itself no longer justifies private possession, arms regulation would withstand attack unless it were a total destruction of the right, or unless, as is more likely, the provisions were construed to include one of the purposes justifying private possession.

86 See text at notes 31-36 supra.

87 See text at notes 37-39 supra.

88 Citations of the statutes can be found in the authorities cited in note 78 supra. The following footnotes cite cases considering the constitutionality of the various statutory provisions.

89 State v. Reid, 1 Ala. 612 (1840); Haile v. State, 38 Ark. 564 (1882); Carlton v. State, 63 Fla. 1, 58 So. 486 (1912); Nunn v. State, 1 Ga. 243 (1846); State v. Hart, 66 Idaho 217, 157 P.2d 72 (1945); State v. Jumel, 13 La. Ann. 399 (1858); Patterson v. State, 251 Miss. 565, 170 So. 2d 635 (1965); State v. Keet, 269 Mo. 206, 190 S.W. 573 (1916); State v. Boone, 132 N.C. 1107, 44 S.E. 595 (1903); State v. Nieto, 101 Ohio St. 409,130 N.E. 663 (1920); Ex parte Thomas, 21 Okla. 770, 97 P. 260 (1908); Wright v. Commissioner, $77 \mathrm{~Pa} .470$ (1875); City of Scranton v. Adams, $20 \mathrm{~Pa}$. Dist. 91 (1909); Aymette v. State, 21 Tenn. 154 (1840); State v. Wilburn, 66 Tenn. 57 (1872).

00 City of Salina v. Blaksley, 72 Kan. 230, 83 P. 619 (1905) (carrying pistol within city while intoxicated); State v. Duke, 42 Tex. 455 (1875) (carrying pistol within city unless able to show immediate danger to person or property). But see In re Brickley, 8 Idaho 
unauthorized bodies of armed men ${ }^{93}$ are common. With the possible exception of the last mentioned practice, ${ }^{94}$ it is unlikely that these laws, which have little effect on widespread availability and ownership of weapons, frustrate the deterrence of oppression purpose. However, it might be argued that these laws impede the purpose of self-defense if they deny an individual the right to carry a weapon when he is most likely to be attacked. This argument is countered by two considerations: the danger of widespread presence of weapons in public places and police protection against attack in these places. ${ }^{95}$ Thus, in view of the benefit to be derived from these laws, place and manner regulations which do not restrict possession in homes or businesses do not seem to subvert unduly the self-defense purpose. ${ }^{96}$

\section{B. Prohibiting Ownership by Certain Classes of Persons}

Almost all states prohibit possession of firearms by certain classes of persons, such as felons and incompetents. ${ }^{97}$ These statutes seem to have

597, 70 P. 609 (1902) (overturning statute barring carrying deadly weapon within city limits).

91 Hill v. State, 53 Ga. 473 (1874).

92 State v. Duranleau, - Vt. 一, 260 A.2d 383 (1969).

93 Presser v. Illinois, 116 U.S. 252 (1886); Commonwealth v. Murphy, 166 Mass. 171, 44 N.E. 138 (1896); State v. Gohl, 46 Wash. 408, 90 P. 259 (1907) (employing unauthorized armed body of men).

94 The training of large groups of men for armed resistance would undoubtedly increase the likelihood that an armed revolt against oppressive government would succeed. However, in view of the danger of such practices to society, the doctrine of deterrence of oppression should not be invoked to justify enabling groups harboring particular political views to attempt to coerce society into adopting those views. The doctrine should be limited to justifying the widespread presence of a reserve of arms among the population at large so that the possibility of their spontaneous resistance to oppressive governmental action remains a formidable factor in the deliberations of a government considering such action. The same reasoning explains why deterrence of oppression should not be considered a justification for excessively dangerous weapons such as machine guns and missiles, see text at notes 101-03 infra, even though the absence of such weapons removes the deterrent effect inherent in the presence of these arms among the population.

95 See State v. Cartwright, 246 Ore. 121, 418 P.2d 822 (1966), cert. denied, 386 U.S. 987 (1967).

96 See cases cited notes 89-93 stupra. See also State v. Plassard, 355 Mo. 90, 195 S.W.2d 495 (1946); State v. Nickerson, 126 Mont. 157, 247 P.2d 188 (1952); Heaton v. State, 130 Tenn. 163, 169 S.W. 750 (1914). These cases uphold the right to bear arms against trespassers and seem to protect possession of arms in one's home or business.

97 Mason v. State, 39 Ala. App. 1, 103 So. 2d 337 (1956), aff'd, 267 Ala. 507, 103 So. 2d 341 (1958) (pardoned felon); Coleman v. State, 32 Ala. 581 (1858) (minor); Nelson v. State, 195 So. $2 d 853$ (Fla. 1967) (felon); Glenn v. State, 10 Ga. App. 128, 72 S.E. 927 (1911) (minor); State v. Bolin, 200 Kan. 370, 436 P.2d 978 (1968) (felon); City of Akron v. Williams, 113 Ohio App. 293, 177 N.E.2d 802 (1960) (felon); State v. Hogan, 63 Ohio St. 202, 58 N.E. 572 (1900) (tramp); State v. Cartwright, 246 Ore. I21, 418 P.2d 822 (1966) (felon); State v. Robinson, 217 Ore. 612, 343 P.2d 886 (1959) (felon); Webb v. State, 439 
no impact on deterrence of oppression, since widespread possession of weapons is not impaired. ${ }^{98}$ They do, however, impede the self-defense capabilities of those in the prohibited class. But since individuals in these groups are considered more likely to misuse weapons than to use them successfully in self-defense, ${ }^{99}$ these regulations seem permissible. ${ }^{100}$

\section{Prohibiting Unusually Dangerous Weapons}

The experience of courts in considering the constitutionality of statutes barring certain classes of weapons can most aptly be described as one of judicial embarrassment over the developments in arms technology. The early theory that dirks, clubs, bowie knifes, pocket pistols, and so on, could be outlawed because they were not "arms" which gentlemen used in civilized warfare ${ }^{101}$ has quickly given way under the onslaught of modern weapons such as machine guns, bazookas and missiles to the theory that some weapons are simply too dangerous to tolerate in a civilized community. ${ }^{102}$ This latter theory hints at the sort of balancing analysis proposed herein: The danger to a neighborhood posed by claymore mines in its midst far outweighs their defensive value to the homeowner; though the elimination of machine guns might inhibit the ability of the population to deter governmental oppression, such action is demanded by the safety of the community.

S.W.2d 342 (Tex. 1969) (felon); State v. Tulley, 198 Wash. 605, 89 P.2d 517 (1939) (felon). See also authorities cited in note 44 supra.

98 This conclusion presumes that the classes prohibited from possession of weapons remain fairly narrow. If they became unduly broadened so that they affected the armsbearing capability of the population at large, then the discussion in the text from notes 104-14 infra would become pertinent.

99 The accuracy of this assumption is significant in determining whether these statutes might be subject to attack under the equal protection clause. See notes 1 \& 44 supra.

100 See State v. Cartwright, 246 Ore. 121, 418 P.2d 822 (1966), cert. denied, 386 U.S. 937 (1967) (rejecting felon's contention that he needed gun for self-defense because he was forewarned of danger with observation that police protection was presumably available).

101 Dabbs v. State, 39 Ark. 353 (1882); Strickland v. State, 137 Ga. 1, 72 S.E. 260 (1911); Ex parte Thomas, 21 Okla. 770, 97 P. 260 (1908); Pierce v. State, 42 Okla. Crim. 272, 275 P. 393 (1929); Andrews v. State, 3 Tenn. 165 (1871); State v. Workman, 35 W. Va. 367, 14 S.E. 9 (1891). See also J.P. Bishop, Statutory Crimes \& 793 (1883). Compare People v. Persce, 204 N.Y. 397 (1912) (slingshot characterized as weapon ordinarily used for criminal and improper purposes as opposed to legitimate weapon for self-defense).

102 People v. Brown, 253 Mich. 537, 235 N.W. 245 (1931) (blackjack). See also State v. Kerner, 181 N.C. 574, 107 S.E. 222 (1921) (limits protection of possession to rifles and pistols); Morrison v. State, 170 Tex. Crim. 218, 339 S.W.2d 529 (1960) (machine gun). See Cases v. United States, I31 F.2d 916 (1942), which criticizes as outdated in an era of commando units the Supreme Court ruling in United States v. Miller, 307 U.S. 174 (1939), that only weapons constituting ordinary military equipment are protected by the second amendment. 
Thus, statutes outlawing exotic weapons may apparently bar all types of firearms except long guns (rifles and shotguns) and hand guns, both of which seem to have developed enough acceptability to take them outside the exotic weapons rubric. ${ }^{103}$ The extent to which use of long guns and hand guns, and especially the latter, may be regulated is now the focal point of the firearms debate.

\section{Restricting Ownership to Individuals Showing a Special Need: The Hand Gun/Long Gun Distinction}

The National Commission on the Causes and Prevention of Violence recommended that possession of hand guns should be limited "to police officers and security guards, small businesses in high crime areas, and others with a special need for self-protection." 104 While no state has yet adopted this proposal explicitly, a few jurisdictions have statutes which in practice might effectively forbid possession of hand guns by all but a very small percentage of the population. ${ }^{105}$ Neither

103 Wilson v. State, 33 Ark. 557 (1887) (carrying army and navy pistols can be regulated but not prohibited); State v. Kerner, 181 N.C. 574, 107 S.E. 222 (1921) (statute requiring permit and bond to possess pistol said to amount to prohibition and as such is overturned); Heaton v. State, 130 Tenn. 163, 169 S.W. 750 (1914) (pistol may be kept in home for protection); Glasscock v. City of Chattanooga, 157 Tenn. 518, 11 S.W.2d 678 (1928) (ordinance banning pistols must make exception for army and navy pistols); State v. Rosenthal, 75 Vt. 295, 55 A. 610 (1903) (pistols may be carried without permission of mayor). But cf. Fife v. State, 31 Ark. 455 (1876) (pocket pistols may be banned).

104 final Report of the National Commission on the Causes and Prevention of Violence, To Establish Justice, To Insure Domestic Tranquility 181 (1969).

105 At present, New York, Massachusetts and New Jersey appear to have such statutes. See N.Y. PEN. LAW \& 400.00(2) which provides for licenses for the possession of hand guns in a home or place of business. Section 400.00(1) requires that no license be "issued or renewed ... except for an applicant .... (d) concerning whom no good cause exists for the denial of the license." Section 400.00(14) authorizes the New York City Council to set the fees for licenses to carry or possess hand guns in that city, which fee it has set at \$20.00 per year. 2 NEw York CITY CHARTER \& CODE $\$ 436-5.0(a)(2)$ (1963). Under N.Y. PEN. LAw §§ 265.05(2)-(3), possession of a hand gun without a license constitutes a misdemeanor, or, if one has previously been convicted of a crime, a felony. MAss. ANN. LAws ch. 140, $\S 131 \mathrm{~A}$ (1965), establishes a license to purchase a firearm-defined in $\S 121$ as a weapon less than 18 inches in length-which the licensing authority may revoke at will. Section 123 prohibits sale to a person not so licensed. N.J. STAT. ANN. \$ 2A:151-32 requires a permit for the purchase of a hand gun and § $2 A: 151-33$ requires that a permit be denied to "any person where the issuance would not be in the interest of the public health, safety or welfare." None of these provisions expressiy limits hand gun possession to the extent recommended by the National Commission on Causes and Prevention of Violence. See text at note 104 supra. But they are all susceptible to liberal interpretations which might allow the licensing authority to follow the Commission's recommendations in practice. Such a liberal construction would have immediate impact on the scope of legal possession in New York where a license is required for possession. In the other states, where a license is required only for purchase, the impact on legal possession would 
the Commission nor any existing statutes have attempted to restrict possession of long guns. The hand gun/long gun distinction is founded both on the existence of legitimate recreational uses of long guns ${ }^{108}$ and on persuasive empirical evidence demonstrating that long guns are not misused nearly as frequently as hand guns. ${ }^{107}$

Restrictive hand gun statutes might conceivably be assailed as undermining both deterrence of oppression and self-defense. However, since hand guns are ineffective for sniping or other long range shooting situations, a restriction or even a ban on possession of hand guns only would not seem to violate a deterrence of oppression purpose. ${ }^{108}$ On the other hand, such statutes might seriously frustrate a self-defense purpose. Most owners of hand guns cite self-defense as the reason for possession. ${ }^{109}$ But empirical studies demonstrate that hand guns are much more likely to be misused than to be successfully used in self-defense. ${ }^{110}$ Moreover, in almost all circumstances the deterrent effect on crime due to hand gun possession appears slight. ${ }^{111}$ On balance, therefore, statutes limiting possession of hand guns to individuals showing a special need for self-defense would seem not to frustrate unduly the self-defense function.

As opposed to restrictive hand gun statutes, proposals which would restrict possession of both hand guns and long guns ${ }^{112}$ appear invalid

be much less pronounced. In addition to the broad grant of discretion to the licensing authority to deny licenses, the $\$ 20.00$ annual fee in New York City certainly discourages applications by those not in need of hand guns for defensive purposes. See also NewIon \& Zimring, supra note 1 , at 89 , which refers to Massachusetts and New York as states where hand guns cannot be owned without a good reason.

100 Note, Firearms: Problems of Control, supra note 78, at 1344.

107 Id. at 1338 n.67. See also NewTon \& ZimRING, supra note 1, at 49: "Although only about 27 percent of the firearms in this country are handguns, they are the predominant firearm used in crime."

108 Recent airplane hijackings suggest that pistols might be very effective for some purposes in a political revolt. However, the doctrine of deterrence of oppression as it developed historically does not justify giving one man, or even fairly large groups, inordinate coercive power. It justifies only leaving a residue of arms among the people so that by spontaneously uniting in resistance they could constitute a formidable force against an oppressive government. See cases cited in note 93 stupra, and discussion in note 94 supra.

100 NEWTON \& ZIMRING, supra note 1, at 61-62.

110 Id. at $62-65$.

111 Id. at 67. The report indicates that the known presence of hand guns in stores located in high crime areas might have a deterrent effect on crime. The presence of hand guns in homes does not have a like effect because home burglaries occur with far greater frequency than robberies, and even in robberies, the criminal has the advantage of surprise. $1 d$. at $63-65$.

112 No such proposals have been adopted and the wide use of long guns for hunting and other recreational purposes might make their enforcement impossible without a 
under arms provisions protecting private possession. First, restricting the widespread availability of all types of arms would seriously undermine the deterrence of oppression purpose. Second, in some instances long guns are relied upon for self-defense. ${ }^{113}$ Moreover, restricting possession of both hand guns and long guns would be subject to attack as a total destruction of the arms right. ${ }^{114}$

\section{E. Transfer Regulations}

Among the common regulations on the sale and transfer of weapons that have been upheld are those outlawing transfer to unauthorized persons ${ }^{115}$ or transfer of prohibited weapons, ${ }^{116}$ those which impose prohibitive taxes to reduce the availability of certain types of weapons, ${ }^{117}$ and those which require dealers to be licensed. ${ }^{118}$ As long as these provisions do not inhibit widespread possession of long guns and, in states where self-defense is a purpose for the right, possession of hand guns by those showing special need, these regulations would seem to have little impact on either deterrence of oppression or selfdefense.

\section{F. Ammunition Control}

The conclusion with respect to transfer regulations would likewise seem applicable to whatever controls are adopted affecting availability of ammunition. ${ }^{119}$ Such controls would seem valid if they leave long

virtual elimination of such sports. However, they are examined here to determine the constitutional limits of gun legislation.

113 See NEWTON \& ZIMRING, supra note 1, at 61. An example of an instance in which a long gun was necessary for protection is found in State v. Rathbone, 110 Mont. 225, 100 P.2d 86 (1940), where the court upheld the right of a rancher to kill elk out of season when necessary for the protection of property. The Montana arms right is one which includes protection of property within the purview of self-defense. See text following note 74 supra. Another example is presented in Note, Firearms Legislation, supra note 78, at 1374, which describes an instance in Tennessee in which rabid foxes were hunted by private citizens.

114 See note 83 supra.

115 Coleman v. State, 32 Ala. 581 (1858) (act forbidding selling, giving or lending weapons to minors); City of Akron v. Williams, 113 Ohio App. 293, 177 N.E.2d 802 (1960), rev'd on other grounds, 175 Ohio St. 186, 192 N.E.2d 63 (1963).

116 Dabbs v. State, 39 Ark. 353 (1882) (selling pocket pistol).

117 Caswell \& Smith v. State, 148 S.W. 1159 (Tex. Ct. Civ. App. 1912) (50\% gross receipts tax imposed on sale of pistols).

118 Biffer v. City of Chicago, 278 Ill. 562, 116 N.E. 182 (1917) (ordinance requiring gun dealers to have a license with a $\$ 25.00$ annual fee); Burton v. Sills, 53 N.J. 86, 248 A.2d 521 (1969); State v. Burgoyne, 75 Tenn. 173 (1881) (act making it a misdemeanor to sell without a license considered where issue was whether act could operate on merchant who had purchased weapons before its passage).

110 For examples of statutes limiting ammunition availability see MASs. ANN. LAWs 
gun ammunition widely available and, in states where self-defense is protected, leave hand gun ammunition available to those showing a special need.

\section{G. License, Registration, Audits}

Statutes requiring licenses for purchase of new guns ${ }^{120}$ or for carrying guns, ${ }^{121}$ registration by those already owning guns, ${ }^{122}$ or periodic audits to ascertain changes in ownership of guns ${ }^{123}$ are usually supportive measures to insure that firearms do not fall into the hands of those not entitled to possess them. As such, they have little impact on possession and would not seem to impede the self-defense function. ${ }^{124}$ Registration statutes have frequently been attacked with the argument that a tyrannical government could more easily confiscate weapons if it knew the identity of gun owners, ${ }^{125}$ thus reducing deterrence of oppression. Though the argument might have some weight if a government were able to act so quickly that resisters were disarmed before having opportunity to organize, the impact on deterrence of oppression does not seem to offset the need for these measures as an aid to enforcement of restrictions on possession. Moreover, the argument against these regulations seems to undercut the very presumption on which the doctrine of deterrence of oppression rests-that people will resist an oppressive government-by presuming that they would meekly allow confiscation to take place.

ch. 140, § 122B (Supp. 1969); N.Y. PEN. LAws § 265.05. However, controls on ammunition do not appear common.

120 Statute upheld in Burton v. Sills, 53 N.J. 86, 248 A.2d 521 (1969).

121 These statutes have been upheld in: Strickland v. State, 137 Ga. 1, 72 S.E. 260 (1911); Glenn v. State, 10 Ga. App. 128, 72 S.E. 927 (1911); Matthews v. State, 237 Ind. 677, 148 N.E.2d 334 (1958); State v. Kerner, 181 N.C. 574, 107 S.E. 222 (1921); People v. Warden, 154 App. Div. 413,139 N.Y.S. 277 (1913).

122 Cases upholding these statutes include: Photos v. City of Toledo, 19 Ohio Misc. 147, 250 N.E.2d 916 (1969); Brown v. City of Chicago, 42 IIl. 2d 501, 250 N.E.2d 129 (1969). 123 See NEwTon \& Zimring, supra note 1, at 84. The authors propose periodic audits similar to tax audits as a means of ascertaining and encouraging compliance with registration statutes.

124 However, these statutes may be drafted or applied so that they themselves define the groups entitled to possession. In such instances, these statutes are subject to the same constitutional analysis given statutes directly regulating possession. See text and note at note 105 supra.

125 BAKAx, supra note 30 , at 202-03, 280, humorously rebuts this argument by quoting the following response of one witness at a congressional hearing to the suggestion that gun registration would enable enemies to identify easily gun owners and to confiscate their weapons:

An efficient army of occupation would probably not take the time and trouble to seize the files of all the police departments and game wardens of the country, but might prefer ... a quick single trip to ... the headquarters of the National Rifle Association. 


\section{H. Waiting Periods}

Waiting periods are also supportive measures. They give investigating agencies time to ascertain whether an individual seeking to purchase a firearm is indeed entitled to possess it. In addition, they prevent acquisition of weapons during sudden emotional outbursts when they might be more likely to be misused. ${ }^{126}$ Waiting periods are conceivably subject to criticism as impairing the self-defense function by preventing an individual who was forewarned of impending danger from acquiring a weapon. However, the possibility of obtaining police protection in such a dilemma ${ }^{127}$ and the utility of waiting periods as an aid to enforcement of other gun measures limit the force of such an objection.

\section{ConcLusion}

While most of the familiar forms of arms regulation seem valid even under arms provisions guaranteeing a right to private possession, those provisions restrict to some extent the scope of permissible gun control. Thus, the analysis set forth establishes a threshold level of constitutionality. The arms provisions invalidate certain types of legislation; but where legislation is deemed constitutional under those provisions, or where there is no provision, the legislation must then be measured by such other requirements as due process, equal protection and the self-incrimination privilege to decide the issue of constitutionality.

126 But see Note, Firearms: Problems of Control, supra note 78, at 1339-40 \& n.78 (concluding that value of cooling off periods is "conjectural at best").

127 See State v. Cartwright, 246 Ore. 121, 418 P.2d 822 (1966), cert. denied, 386 U.S. 987 (1967). 